\title{
The estimation of crude protein and dry matter degradability of maize and grass silages by near infrared spectroscopy
}

\author{
Begoña De la Roza, Adela Martínez and Begoña Santos \\ Centro de Investigación Aplicada y Tecnología Agroalimentaria (CIATA), Dpto. Producción Animal, Pastos y \\ Forrajes, Apdo 13-33300 Villaviciosa, Spain.E-mail: begonard@princast.es.
}

\author{
Javier González and Guillermo Gómez \\ ETSI Agrónomos, Dpto. Producción Animal, Ciudad Universitaria, 28040 Madrid, Spain.
}

\begin{abstract}
A total of 130 silages samples ( 53 of maize silages and 77 of grass silages ), which were ensiled with or without silage additives, with different soil contamination levels, with different weed percentages and with or without wilting, were used to evaluate the dry matter (DM) and crude protein (CP) ruminal degradability. The ruminal degradability of the samples was calculated from the corresponding in situ degradation parameters and from the measured passage rates of the silages fed to each experimental animal. The DM and CP degradation parameters were obtained using the logistic model of Van Milgen and Baumont. The fitting of the models to the kinetics of degradation and particle passage was carried out by non-linear regression. The value of the effective degradability, considering in the rumen simultaneously an outflow compartment and a mixing-reduction compartment, were calculated in both cases from an adaptation of the general procedure proposed by Ørskov and McDonald. A NIRSystems 6500 spectrometer was used for the prediction of the DM and the CP degradation characteristics of the samples. Calibration equations were obtained by modified partial least squares regression, using reflectance spectra transformed into the second derivative. The results showed that near infrared spectroscopy is a good method for predicting the DM and CP degradation characteristics. The calibrations for effective degradability of maize and grass silages indicated a high consistency.
\end{abstract}

Keywords: grass silages, maize silages, degradation, protein, dry matter, near infrared spectroscopy, NIR.

\section{Introduction}

The new rationing systems for ruminants ${ }^{1-4}$ require knowledge of the crude protein $(\mathrm{CP})$ rumen degradability values. The availability of in vivo and in sacco degradability values are limited because those methods require work with fistulated animals and are rather complicated, labour intensive and expensive. That is to say, the dynamics and logistics of the methodology result in considerable work, due to limitations on the amount of samples, number of bags that can be placed in an animal and different time intervals to perform kinetic studies. ${ }^{5}$ Therefore, a simpler method is necessary to estimate the degradation characteristics of the feeds.

Near infrared (NIR) reflectance spectroscopy is a widely used and successful tool in animal nutrition 
which has been in use since the seventies and it might be expected that NIR reflectance spectroscopy could be used for the prediction of dry matter (DM) and crude protein (CP) degradation characteristics of forages. . $^{6,7}$

Each feed sample has a particular degradability value which is required to be known for ration evaluation and so farm advisory organisations need accurate feed evaluation methods, which must be rapid and cheap to operate. Such methods must also be robust and potentially applicable to all samples. If NIR reflectance spectroscopy could be used to determine the DM and CP degradation characteristics of forages, considerable time and effort could be saved.

The objective of this work was to study the potential of NIR reflectance spectroscopy to determine the DM and CP degradation characteristics of silages.

\section{Materials and methods}

\section{Population definition}

A total of 130 silages samples (53 of maize silages and 77 of grass silages) were evaluated using the in situ method. Both, maize and grass silages, were ensiled with or without silage additives, with different soil contamination levels, with different weed percentages and with or without wilting (Figures 1 and 2).

The ruminal degradability of the samples was calculated from the corresponding in situ degradation parameters and from the passage rates of the silage fed to each experimental animal. Afterwards a mean value was calculated for each sample.

\section{Degradation}

The in situ degradation was obtained with two groups of three rams of $65 \mathrm{~kg}$ mean live weight (LW) of the manchega sheep breed, which were fistulated in the rumen and in the proximal duodenum. The first group was used for the samples of grass silages, while the second group was used for the samples of maize silages. The animals were fed at a level of $40 \mathrm{~g}$ of DM kg-1 $\mathrm{LW}^{-0.75}$ with mixed rations of silage and concentrate, in a proportion $2: 1$ on DM basis, distributed in two equal daily feedings at $9.00 \mathrm{~h}$ and $17.00 \mathrm{~h}$. Ration silages were of grass and maize for the first and second group of animals, respectively.

The samples had been previously freeze-dried and milled through a $2 \mathrm{~mm}$ exit sieve. These were incubated in duplicate in nylon bags, in two series, which included periods of $0,3,6,12,24,48$ and $72 \mathrm{~h}$ and an additional period of $96 \mathrm{~h}$ for the maize silage

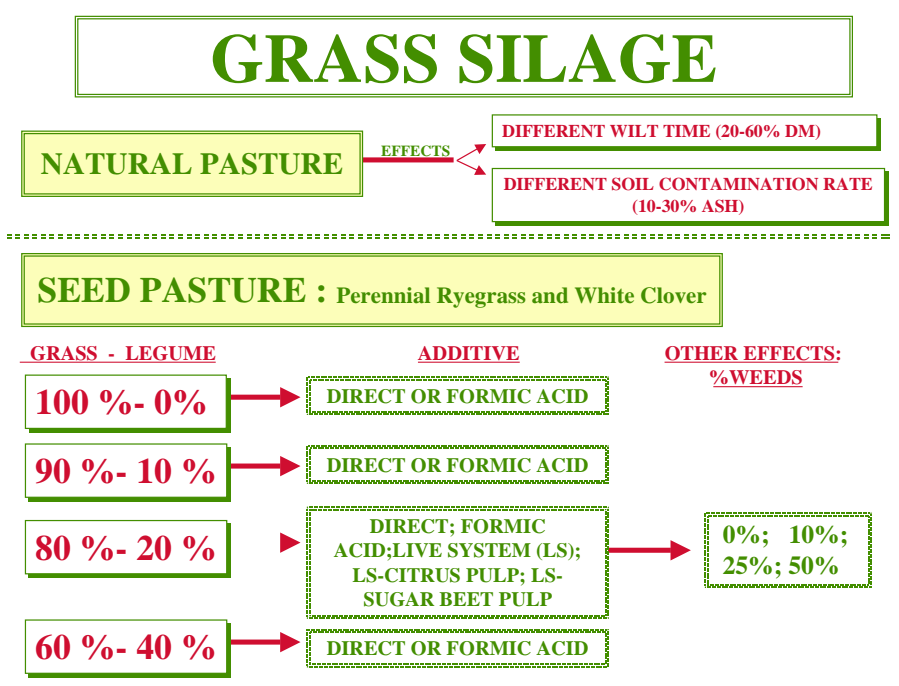

Figure 1. Different pastures, additives and other effects considered on grass silages. 


\section{MAIZE SILAGE}

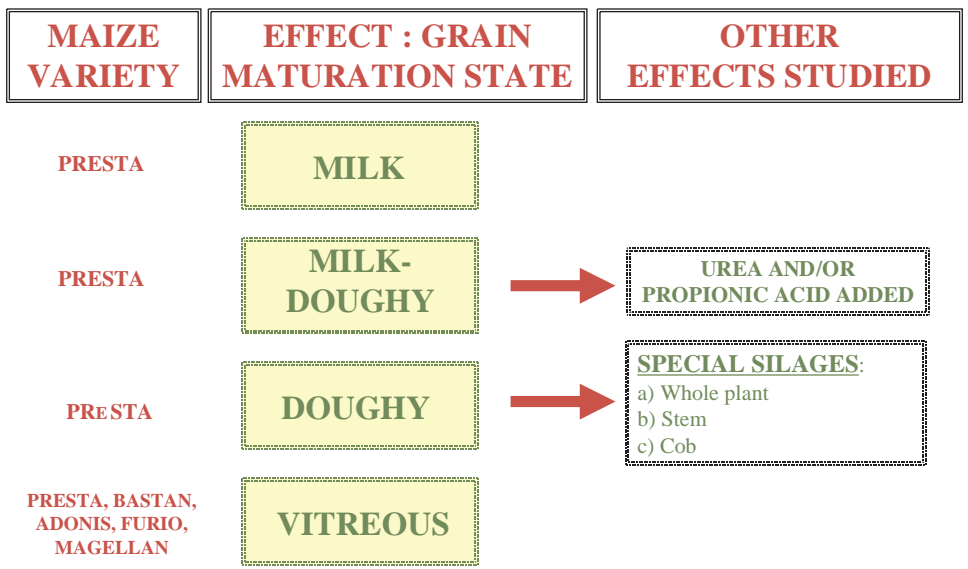

Figure 2. Different varieties, grain maturation states and other effects considered on maize silages.

samples. The method of Michalet-Doreau et al. ${ }^{8}$ was followed for the incubations and the subsequent processing of the bags to obtain the in situ degradadation parameters of DM and CP. The disappearance of $\mathrm{DM}$ and $\mathrm{CP}$ were expressed as the percentage of the respective initial content in the sample.

The logistic model used by Van Milgen and Baumont ${ }^{9}$ was fitted to these degradation results. The mathematical expression of this model is:

$$
D_{t}=a+b\left(c_{0}-c_{0} \mathrm{e}^{-c \infty t}\right) /\left(c_{0}+\left(c-c_{0}\right) \mathrm{e}^{-c \infty t}\right)
$$

where $D_{t}=$ in situ degradation at time $t, a=$ soluble fraction at time $0, b=$ degradable fraction at time 0 , $c_{0}=$ initial fractional rate of degradation of $b, c=$ final fractional rate of degradation of $b$.

\section{Particle passage}

In order to estimate the effective degradability, two rumen rates corresponding to the diet silage were determined: the outflow rate of small particles and the rate for mixing and reduction from large to small particles. These rates were obtained from the evolution of the Ytterbium concentration of the digesta in the duodenum, after the lambs had ingested, half an hour before the morning meal and in a simple dose, $40 \mathrm{~g}$ of DM of silage labelled with Yt- terbium according to the method of Ellis and Beever. ${ }^{10}$ Nineteen samples of duodenal digesta were taken, approximately of $80 \mathrm{~mL}$, the first just before and the others during the $96 \mathrm{~h}$ subsequent to the ingestion of the labelled silage. These samples were immediately frozen at $-20^{\circ} \mathrm{C}$ for subsequent analysis. The Ytterbium was quantified by atomic absorption spectrophotometry.

The model of Grovum and Williams ${ }^{11}$ was fitted to the evolution of the Ytterbium concentration. The smallest rate was assigned to the outflow of small particles from the rumen, because this compartment has the slowest rate, while the greatest rate was associated with the mixing-reduction compartment.

\section{Model fitting and degradability}

The fitting of the models to the kinetics of degradation and particle passage was carried out by nonlinear regression with the NLIN procedure of the SAS statistical package. ${ }^{12}$ The ruminal degradability of the samples was calculated from the corresponding in situ degradation parameters and from the passage rates of the silage fed to each experimental animal. Afterwards a mean value was obtained for each sample.

The values for the effective degradability $(E D)$, considering in the rumen simultaneously an outflow 
compartment and a mixing-reduction compartment, were calculated from an adaptation of the general procedure proposed by Ørskov and McDonald, ${ }^{13}$ with the expression:

$$
E D=a+\int_{0}^{\infty} f_{t} \mathrm{~d} D_{t} / \mathrm{d} t \mathrm{~d} t(\text { in our notation })
$$

where $D_{t}$ and $f_{t}$ are, respectively, the in situ degradation and the calculated fraction of remaining labelled particles in the rumen, which was calculated considering not only the fractional outflow rate but also the rate of mixing and reduction of particles. The values were calculated, through numerical integration.

\section{Chemical analyses}

Chemical analyses for DM, $\mathrm{CP}^{14}$ and acid detergent insoluble nitrogen ${ }^{15}$ (ADIN) on unincubated silages samples, were conducted in duplicate on the freeze-dried subsamples (thus avoiding Maillard reactions) and milled to $0.75 \mathrm{~mm}$.

\section{NIR scanning and calibration procedures}

For the NIR measurements, the freeze-dried and ground samples were scanned, using a NIRSystems 6500 scanning monochromator (NIRSystems, Inc., Silver Spring, MD, USA) over a wavelength range from 400 to $2500 \mathrm{~nm}$. Spectra were collected as log $1 / R$. Population boundaries were established with a maximum standardised $H$ distance from the average spectrum of 3.0. ${ }^{16}$ Two of the samples were identified from NIR reflectance spectroscopy spectra as outliers: a grass silage of natural pasture with $580 \mathrm{~g} \mathrm{~kg}^{-1} \mathrm{DM}$ and another grass silage of sown pasture with $25 \%$ of weeds. These outliers were discarded. Calibration equations were obtained by ISI sofware (Infrasoft International, Port Matilda, PA, USA), using a full wavelength range every 8 th wavelength using modified partial least squares as the regression method. Several methods for scatter correction such as detrend, standard normal variate, multiple scatter correction and combination of detrend and standard normal variate and different mathematical treatment (first and second derivative), different segment length over which the derivative was taken and different length of the smoothing segments were used. ${ }^{17,18}$ Cross validation, to minimise overfitting of the equation, was used to test the calibration equations. Each equation selected was evaluated according to the lowest standard errors [standard error of calibration $(S E C)$ and standard error of cross validation ( $S E C V$ ), respectively] and the highest coefficients of determination $\left(R^{2}\right.$ and $\left.C V r^{2}\right)$.

\section{Results and discussion}

The range and standard deviation $(S D)$ of the samples utilised and the best statistical parameters for the CP and DM degradation characteristics and ADIN for the calibration equations obtained are summarised in Table 1, Table 2 and Table 3. Calibration equations were obtained by modified partial least squares regression, using second derivative.

In order to decide if a calibration equation is acceptable for predicting, the ratio of the standard deviation of the reference data to $S E C V$ and the ratio of the reference data range to $S E C V$ were calculated. Values for the ratio $S D / S E C V$ should be ideally at least three, although 2.5 is acceptable, and for the ratio Range/SECV at least ten. ${ }^{19}$

Principal wavelengths were highlighted using stepwise regression. In the case of $a$ and $b$ for $\mathrm{CP}$ fractions, the segment with higher $F$ statistic was $2060 \mathrm{~nm}$ ( $F=231$ for $a$ and $F=247$ for $b$ fractions), respectively. This region might be related mainly to absorption of protein. For $a$ and $b$ DM fractions the wavelength segments more important as explanatory variables were 2268 and $2284 \mathrm{~nm}$ ( $F=115$ for $a$ and $F=141$ for $b$ fractions), respectively. The $2268 \mathrm{~nm}$ region may respond to $-\mathrm{OH}$ stretch $-\mathrm{OH}$ deformation combination band structure, related to absorption of starch, probably related to rumen degradable starch for maize silages. This band, $2268 \mathrm{~nm}$, might be also related with the rupture of protein hydrogen bridges, this is to say with the soluble protein fraction. And the longest wavelength feature (2284 nm) may originate in a $-\mathrm{CH}$ stretch $-\mathrm{CH}$ deformation combination band structure, possible from carbohydrate material. ${ }^{20}$

For most properties measured, accuracy of NIR reflectance spectroscopy calibrations was either high or promising, although it is heavily dependent on the accuracy of the reference data. The only exception were the prediction of the degradation frac- 
Table 1. Range of crude protein degradability characteristics of samples and NIR reflectance spectroscopy calibration statistics.

\begin{tabular}{|l|c|c|c|c|c|c|c|c|}
\hline Parameters & Range & $S D$ & $S E C$ & $R^{2}$ & $S E C V$ & $C V r^{2}$ & Range/SECV & SD/SECV \\
\hline$a(\%)$ & $44.07-74.89$ & 8.215 & 3.289 & 0.840 & 3.884 & 0.779 & 7.94 & 2.12 \\
\hline$b(\%)$ & $5.75-40.23$ & 8.226 & 2.576 & 0.902 & 3.521 & 0.819 & 9.79 & 2.34 \\
\hline$(a+b)(\%)$ & $72.35-91.56$ & 5.027 & 0.965 & 0.963 & 1.535 & 0.907 & 12.51 & 3.27 \\
\hline$c_{0}\left(\mathrm{~h}^{-1}\right)$ & $0.001-0.109$ & 0.023 & 0.011 & 0.787 & 0.015 & 0.594 & 7.33 & 1.57 \\
\hline$c\left(\mathrm{~h}^{-1}\right)$ & $0.015-0.249$ & 0.060 & 0.040 & 0.551 & 0.044 & 0.451 & 5.27 & 1.35 \\
\hline$E D(\%)$ & $68.62-88.15$ & 6.034 & 1.458 & 0.942 & 2.228 & 0.866 & 8.77 & 2.71 \\
\hline
\end{tabular}

Table 2. Range of dry matter degradability characteristics of samples and NIR reflectance spectroscopy calibration statistics.

\begin{tabular}{|l|c|c|c|c|c|c|c|c|}
\hline Parameters & Range & $S D$ & $S E C$ & $R^{2}$ & $S E C V$ & $C V r^{2}$ & Range/SECV & SD/SECV \\
\hline$a(\%)$ & $21.73-49.02$ & 7.199 & 1.563 & 0.953 & 1.803 & 0.938 & 15.14 & 3.99 \\
\hline$b(\%)$ & $28.75-55.32$ & 7.271 & 1.865 & 0.934 & 2.565 & 0.876 & 10.36 & 2.83 \\
\hline$(a+b)(\%)$ & $59.41-83.31$ & 6.653 & 1.507 & 0.949 & 2.247 & 0.888 & 10.64 & 2.96 \\
\hline$c_{0}\left(\mathrm{~h}^{-1}\right)$ & $0.006-0.046$ & 0.009 & 0.004 & 0.837 & 0.005 & 0.674 & 7.88 & 1.76 \\
\hline$c\left(\mathrm{~h}^{-1}\right)$ & $0.029-0.193$ & 0.043 & 0.015 & 0.875 & 0.021 & 0.767 & 8.00 & 2.08 \\
\hline$E D(\%)$ & $50.74-75.69$ & 7.318 & 2.184 & 0.911 & 2.588 & 0.878 & 9.64 & 2.83 \\
\hline
\end{tabular}

Table 3. Range of acid detergent insoluble nitrogen of samples and NIR reflectance spectroscopy calibration statistics.

\begin{tabular}{|l|c|c|c|c|c|c|c|c|}
\hline Parameters & Range & $S D$ & $S E C$ & $R^{2}$ & $S E C V$ & $C V r^{2}$ & Range/SECV & $S D / S E C V$ \\
\hline $\begin{array}{l}\text { ADIN g kg } \\
\text { DM on }\end{array}$ & $0.35-1.66$ & 0.361 & 0.077 & 0.954 & 0.113 & 0.904 & 11.59 & 3.19 \\
\hline
\end{tabular}

tional rates $\left(c_{0}, c\right)$. In general, the results obtained are similar to those reported by Waters and Givens ${ }^{6}$ and Todorov et al. ${ }^{21}$

The relationship between the NIR data and the degradation characteristics was weaker for CP than DM, according to Todorov et al. ${ }^{21}$ and Atanassova et $a l .{ }^{7}$ except for the sum of the $a$ and $b$ fractions $(a+b)$. CP degradability values could be less accu- rate because no account was taken of possible microbial contamination of the bag residues. The nitrogen content of maize silages is lower than grass silages, for this reason the effect of microbial contamination will be larger, however, the effect of microbial contamination in this study was diluted by the wide internal variation of values the degradation parameters. 
In another hand, it is also necessary to know the ADIN value to enable animal production professionals to formulate rations, because the proportion of $\mathrm{N}$ which is insoluble in acid detergent is closely and inversely related with the true absorption of $\mathrm{N}$ from the undegradable $\mathrm{N}$ fraction (UDN) of feeds. ${ }^{22}$ The calibration equation selected for ADIN has good accuracy.

It may be expected that with a separate calibration for each type of silage and different effects considered, better results might be obtained. However, separate calibration showed poor results.

Finally, the $S D / S E C V$ values for $a$ and $b$ fractions for $\mathrm{CP}$ are rather low to use the calibration equations routinely with sufficient accuracy, however, it is possible to contrast the $E D$ calculated from the predicted values for $a, b, c_{0}$ and $c$ with the directly predicted $E D$ values. In addition, ADIN could be successfully estimated by NIR reflectance spectroscopy to apply in rationing systems.

In conclusion, with suitable calibrations for NIR reflectance spectroscopy, the intensive labour required to obtain the degradation characteristics for a given silage sample could be reduced without losing accuracy.

\section{Acknowledgements}

The authors would like to thank $\mathrm{Dr} A$. Argamentería, Head of Animal Production Department, for discussions and useful suggestions and S. Modroño for the ADIN analyses. We also thank the Interministerial Commission for Science and Technology (CICYT) for financial support.

\section{References}

1. INRA, Prévision de la Valeur Nutritive des Aliments des Ruminants, Tables de Prévision de la Valeur Alimentaire des Fourrages. INRA Publications, Route de St-Cyr, 78000 Versailles (1981).

2. ARC, The Nutrient Requirements of Ruminant Livestock, Supplement $N^{o}$. 1, Technical review by an Agricultural Research Council working party. Commonwealth Agricultural Bureaux, Farnham Royal, Slough, England (1984).

3. NRC, Ruminant Nitrogen Usage. National Academy Press, Washington, DC (1985).

4. AFRC, Energy and Protein Requirements of Ruminants. CAB International, Wallinford, Oxon, UK (1993).

5. J.E. Nocek and J.E. English, J. Dairy Sci. 69, 77 (1986).

6. C.J. Waters and D.I. Givens, Anim. Sci. Technol. 38, 335 (1992).

7. S. Atanassova, N. Todorov and D. Pavlov, in Leaping Ahead with Near Infrared Spectroscopy, Ed by G.D. Batten, P.C. Flinn, L.A. Welsh and A.B. Blakeney. RACI, Victoria, Australia, p. 495 (1995).

8. B. Michalet-Doreau, R. Verité and P. Chapoutot, Bull. Tech., CRZV Theix, INRA 69, 5 (1987).

9. J. Van Milgen and R. Baumont, British J. Nutr. 73, 793 (1995).

10. W.C. Ellis and K.C. Beever, in Techniques in Particle Size Analysis of Feed and Digesta in Ruminants, Ed by C.P.M. Kennedy. J. Can. Soc. Anim. Sci., p. 154 (1984).

11. W.L. Grovum and V.J. Williams, British J. Nutr. 30, 313 (1973).

12. SAS, SAS/STAT User's Guide, Ver. 6, Fourth Edition, Vol. 1 and 2. SAS Institute Inc., North Carolina (1990).

13. E.R. Ørskov and I. McDonald, J. Agri. Sci., Camb. 92, 499 (1979).

14. A.J.M. Van Es and J. Van der Meer, in Methods of Analysis for Predicting the Energy and Protein Value of Feeds for Farm Animals. Institute for Livestock Feeding and Nutrition Research, Lelystad, The Netherlands (1980).

15. H.K. Goering and P.J. Van Soest, in Forage Fiber Analysis, Agriculture Handbook $N^{\circ} 379$. US Dep. Agric., Washington, DC (1970).

16. J.S. Shenk and M.O. Westerhaus, Crop Sci. 31, 1148 (1991).

17. G. Sinnaeve, P. Dardenne and R. Agneessens, J. Near Infrared Spectrosc. 2, 163 (1994).

18. B. de la Roza, A. Martínez, O. Fernández, B. Santos and S. Modroño, Pastos, XXV(1), 99 (1995). 
19. P.C. Williams and D. Sobering, in Near Infrared Spectroscopy: The Future Waves, Ed by A.M.C. Davies and P.C. Williams. NIR Publications, Chichester, UK, p. 185 (1996).

20. G. Dowey and J. Boussion, in Near Infrared Spectroscopy: The Future Waves, Ed by A.M.C. Davies and P.C. Williams. NIR Publications, Chichester, UK, p. 410 (1996).
21. N. Todorov, S. Atanassova, D. Pavlov and R. Grigorova, Livestock Prod. Sci. 39, 84 (1994).

22. AFRC Technical Committee on Responses to Nutrients, Report No. 9, Nutrition Abstracts \& Reviews, Ser. B 62, 787 (1992).

Received: 15 September 1997 Revised: 30 March 1998 Accepted: 18 June 1998 